\title{
A Study on Some Physical and Engineering Properties of the Chickpea Seeds
}

\author{
Shubham Sinha*, Ajay Verma and Shambu Singh \\ Department of Farm Machinery and Power Engineering, SVCEAT \& RS, FAE, \\ IGKV Raipur (C.G.), India \\ *Corresponding author
}

\section{A B S T R A C T}

\section{Keywords}

Width, Thickness, Sphericity, Aspect ratio, Geometric mean diameter

Article Info

Accepted:

12 October 2019

Available Online:

10 November 2019
The study showed that the physical and engineering properties of 20 chickpea seeds such as length, width, thickness, sphericity, aspect ratio, geometric mean diameter, thousand seed weight, bulk density and moisture content. The average length, width, thickness, sphericity, aspect ratio, geometric mean diameter, thousand seed weight, bulk density and angle of repose are $8.48 \mathrm{~mm}, 6.45 \mathrm{~mm}, 6.03 \mathrm{~mm}, 0.81,75.54 \%, 6.90 \mathrm{~mm}, 244.85 \mathrm{~g}$, $709.55 \mathrm{~kg} / \mathrm{m}^{3}$ and $19.81 \%$ respectively. This study is useful for design of metering mechanism for chickpea seeds.

\section{Introduction}

Chickpea (Cicer arietinum L.) is the secondmost important pulse crop after pigeonpea in the World for human diet and other use. It is cultivated in area of 13.54 million hectares with a total production of 13.10 million tonnes and average productivity of $967.6 \mathrm{~kg} / \mathrm{ha}$ (FAO 2013). Chickpea is an important winter season pulse crop in India grown as a dry pulse crop or as a green vegetable with the former use being most common. It ranks first in area cultivated in India, grown over an area of 8.11 million hectares with production of 5.9 million tones with average productivity of $727 \mathrm{~kg} / \mathrm{ha}$ (Anonymous, 2016). Madhya Pradesh, Uttar
Pradesh, Rajasthan, Maharashtra, Gujarat, Andhra Pradesh and Karnataka are the major chickpea producing states sharing over $95 \%$ area. It is a key source of protein and it plays an important role in human nutrition for large population in the developing world. Chickpea valued for its nutritive seeds with high protein content (18-22\%), carbohydrate (52-70\%), fat (4-10\%), fiber (3\%), minerals (calcium, magnesium, phosphorus, iron, zinc) and vitamins. Chickpea also plays a main role in increasing soil fertility due to its nitrogen fixing ability. Chickpea can fix up to 140 $\mathrm{kgN} / \mathrm{ha}$ in a growing period (Poonia and Pithia 2013). It leaves substantial amount of residual nitrogen for subsequent crops and adds plenty 
of organic matter to maintain and improve soil health and fertility.

Chhattisgarh state has good agro-ecological situation for chickpea production. In state it is grown over an area of 356.52 thousand hectares with an annual production of 433.15 thousand tonnes and an average productivity of $1140 \mathrm{~kg} / \mathrm{ha}$ (Anonymous, 2016).

\section{Materials and Methods}

The seeds of chickpea were procured from Department of Agronomy, Indira Gandhi Krishi Vishwavidyalaya (IGKV), Raipur. The shape and size of the chickpea was ascertained with three perpendicular dimensions, length (L), width (W) and thickness (T). The physical dimensions were determined randomly measuring the length, width and thickness of 10 kernels of each seeds using digital type vernier callipers having least count $0.01 \mathrm{~mm}$ (Fig. 1). The size and shape of the seeds will be useful in deciding the size and shape of orifice of metering mechanism.

Measurement of average length $(\mathrm{L})$, width (W) and thickness (T)

Average length (L), width (W) and thickness (T) is calculated by using the expressions as suggested by Singhal et al., (2003).

$$
\begin{aligned}
& L=\frac{\sum_{i=1}^{n} L}{n} \\
& W=\frac{\sum_{i=1}^{n} W}{n} \\
& T=\frac{\sum_{i=1}^{n} T}{n}
\end{aligned}
$$

Where,

$\mathrm{L}=$ largest intercept (length), mm;

$\mathrm{W}=$ width, $\mathrm{mm}$; and
$\mathrm{T}=$ thickness, $\mathrm{mm}$

\section{Geometric mean diameter $\left(D_{p}\right)$}

The geometric mean diameter $\left(D_{p}\right)$ was calculated by using the following relationship (Mohsenin, 1986).

$$
\mathrm{D}_{\mathrm{p}}=(\mathrm{LWT})^{1 / 3}
$$

Where

$\mathrm{L}=$ largest intercept (length), $\mathrm{mm}$

$\mathrm{W}=$ width, $\mathrm{mm}$

$\mathrm{T}=$ Thickness, $\mathrm{mm}$

\section{Sphericity $(\phi)$}

Sphericity defines the ratio of the diameter of a sphere of the same volume as that of the particle and the diameter of the smallest circumscribing sphere or generally the largest diameter of the particle (Sahay and Singh, 1994).

\section{Sphericity}

$=\sqrt{\frac{\text { Volume of the particle }}{\text { volume of circumdsribed sphere }}}=\frac{(L W T)^{1 / 3}}{L}$

Where,

$\mathrm{L}=$ largest intercept (length), $\mathrm{mm}$;

$\mathrm{W}=$ width, $\mathrm{mm}$;

$\mathrm{T}=$ Thickness, $\mathrm{mm}$.

\section{Aspect ratio}

The aspect ratio is defines by the ratio of width of the seeds to the length of seeds into 100. Ra of the chickpea seeds was determined as recommended by using equation: 
$R a=\frac{W}{L} \times 100$

Where,

$\mathrm{Ra}=$ Aspect ratio, \%;

$\mathrm{L}=$ Length, $\mathrm{mm}$;

$\mathrm{W}=$ Width, $\mathrm{mm}$

\section{Mass of chickpea seeds}

To obtain the mass, 1000 randomly selected chickpea seeds were weighed by using electronic balance with a least count up to $0.001 \mathrm{~g}$.

\section{Bulk density of chickpea seeds}

Bulk density of chickpea seeds was calculated by placing the sample of chickpea seeds in a cylinder which has $7 \mathrm{~cm}$ of diameter and 9.6 $\mathrm{cm}$ of length. (Madamaba et al., 1993). The sample placed in the cylinder is then weighed by using electronic balance with least count of 0.001g. Bulk density was calculated by using the relationship.

$\mathrm{b}_{\mathrm{d}}=\frac{\mathrm{wt}}{\mathrm{L} \times\left(\pi \mathrm{d}^{2} / 4\right)}$

Where,

$\mathrm{b}_{\mathrm{d}}=$ bulk density, $\mathrm{kg} / \mathrm{m}^{3}$

$\mathrm{W}_{\mathrm{t}}=$ weight of sample, $\mathrm{kg}$

$\mathrm{L}=$ length of cylinder, $\mathrm{m}$ and

$\mathrm{d}=$ Diameter of cylinder, $\mathrm{m}$.

\section{Moisture content of the chickpea seeds}

The moisture content can be determined by oven dry method, which is a direct method. The grain is weighed and dried, then weighed again according to standardized procedures. Grain moisture content is expressed as a percentage of moisture based on wet weight (wet basis) or dry matter (dry basis). Wet basis moisture content is generally used. Dry basis is used primarily in research. So we used dry basis method of moisture content determination. Moisture content of the sample was determined by standard air oven method.

Test sample of $5 \mathrm{~g}$ was kept for one hour in hot air electric oven maintained at $130 \pm 2^{\circ} \mathrm{C}$. The sample was drawn from the oven and placed in a desiccator for cooling to ambient temperature.

After cooling, the weight of the sample was taken precisely (within $0.1 \%$ ). The loss in weight was determined and moisture content was calculated using the following expression:

$\mathrm{MC}(\%) \mathrm{db}=\frac{w-d}{d}$

Where,

$\mathrm{w}=$ wet weight;

$\mathrm{d}=$ dry weight;

$\mathrm{MC}=$ moisture content of percent basis

\section{Results and Discussion}

Physical properties such as length, width, thickness, sphericity and thousand grain weights were studied for seeds like Chickpea. The variety of the chickpea seeds taken for study was JG-130 (Table 1).

The average length, width and thickness were found to be $8.48 \mathrm{~mm}, 6.45 \mathrm{~mm}$ and $6.03 \mathrm{~mm}$ respectively. The average Sphericity and geometric mean diameter of chickpeas was calculated 0.81 and $6.90 \mathrm{~mm}$ respectively. Average weight of 1000 grain of chickpea seed was observed $244.85 \mathrm{~g}$. Average aspect 
ratio, surface area, bulk density, and moisture content of chickpea were observed $75.54 \%$, $157.379 \mathrm{~mm}^{2}, 709.55 \mathrm{~kg} / \mathrm{m}^{3}, 19.81 \%$ and $18.62 \%$ respectively.

The following conclusions are drawn from the study on engineering properties of chickpea seeds :
Mean length, breadth, thickness and geometric mean diameter of chickpea seeds are $8.48 \mathrm{~mm}$, $6.45 \mathrm{~mm}, 6.03 \mathrm{~mm}, 0.81$ respectively.

After measurement the physical properties of chickpea i.e. average aspect ratio, bulk density, moisture content and porosity of chickpea were observed $75.54 \%, 709.55$ $\mathrm{kg} / \mathrm{m}^{3}, 19.81 \%$ and $18.62 \%$ respectively.

Table.1 Physical parameter of chickpea seeds

\begin{tabular}{|c|c|c|c|c|c|c|}
\hline $\begin{array}{c}\text { Observ } \\
\text { ations }\end{array}$ & $\begin{array}{c}\text { Length, } \\
\text { mm }\end{array}$ & $\begin{array}{c}\text { Width, } \\
\mathbf{m m}\end{array}$ & Thickness, mm & Sphericity & $\begin{array}{c}\text { Geometric } \\
\text { Mean Dia }\end{array}$ & $\begin{array}{c}\text { Weight } \\
\text { of } \mathbf{1 0 0 0} \\
\text { seeds, }\end{array}$ \\
\hline $\mathbf{1}$ & 8.72 & 7.06 & 6.63 & 0.85 & 7.41 & 244.1 \\
\hline $\mathbf{2}$ & 8.86 & 6.27 & 6.23 & 0.79 & 7.02 & 245 \\
\hline $\mathbf{3}$ & 8.59 & 6.60 & 6.15 & 0.81 & 7.03 & 240.5 \\
\hline $\mathbf{4}$ & 8.89 & 6.35 & 6.02 & 0.78 & 6.97 & 246.2 \\
\hline $\mathbf{5}$ & 9.21 & 7.02 & 6.32 & 0.8 & 7.42 & 244.5 \\
\hline $\mathbf{6}$ & 8.54 & 6.30 & 5.87 & 0.79 & 6.8 & 247 \\
\hline $\mathbf{7}$ & 8.81 & 5.91 & 5.68 & 0.75 & 6.66 & 246.5 \\
\hline $\mathbf{8}$ & 8.75 & 6.78 & 6.45 & 0.82 & 7.25 & 245 \\
\hline $\mathbf{9}$ & 8.05 & 6.97 & 6.69 & 0.89 & 7.21 & 248 \\
\hline $\mathbf{1 0}$ & 8.67 & 6.44 & 6.08 & 0.8 & 6.97 & 245.5 \\
\hline $\mathbf{1 1}$ & 8.27 & 6.90 & 6.32 & 0.86 & 7.11 & 244.2 \\
\hline $\mathbf{1 2}$ & 9.38 & 6.59 & 6.23 & 0.77 & 7.27 & 244.4 \\
\hline $\mathbf{1 3}$ & 8.39 & 6.68 & 6.28 & 0.84 & 7.06 & 246 \\
\hline $\mathbf{1 4}$ & 7.67 & 6.00 & 5.79 & 0.84 & 6.5 & 243 \\
\hline $\mathbf{1 5}$ & 8.89 & 6.16 & 5.55 & 0.75 & 6.72 & 242.5 \\
\hline $\mathbf{1 6}$ & 7.69 & 6.26 & 5.87 & 0.85 & 6.56 & 244.6 \\
\hline $\mathbf{1 7}$ & 8.36 & 6.47 & 5.47 & 0.79 & 6.66 & 244.7 \\
\hline $\mathbf{1 8}$ & 7.41 & 5.79 & 5.5 & 0.83 & 6.17 & 244.4 \\
\hline $\mathbf{1 9}$ & 8.41 & 5.74 & 5.01 & 0.74 & 6.23 & 245 \\
\hline $\mathbf{2 0}$ & 8.23 & 6.76 & 6.47 & 0.86 & 7.11 & 246 \\
\hline $\mathbf{A v g e}$ & 8.48 & 6.45 & 6.03 & 0.81 & 6.90 & 244.85 \\
\hline SD & 0.50 & 0.40 & 0.43 & 0.04 & 0.35 & 1.64 \\
\hline $\mathbf{C V} \%$ & 0.25 & 0.16 & 0.18 & 0.001 & 0.13 & 2.72 \\
\hline & & & & & & \\
\hline
\end{tabular}


Fig.1 some physical properties of the chickpea seeds
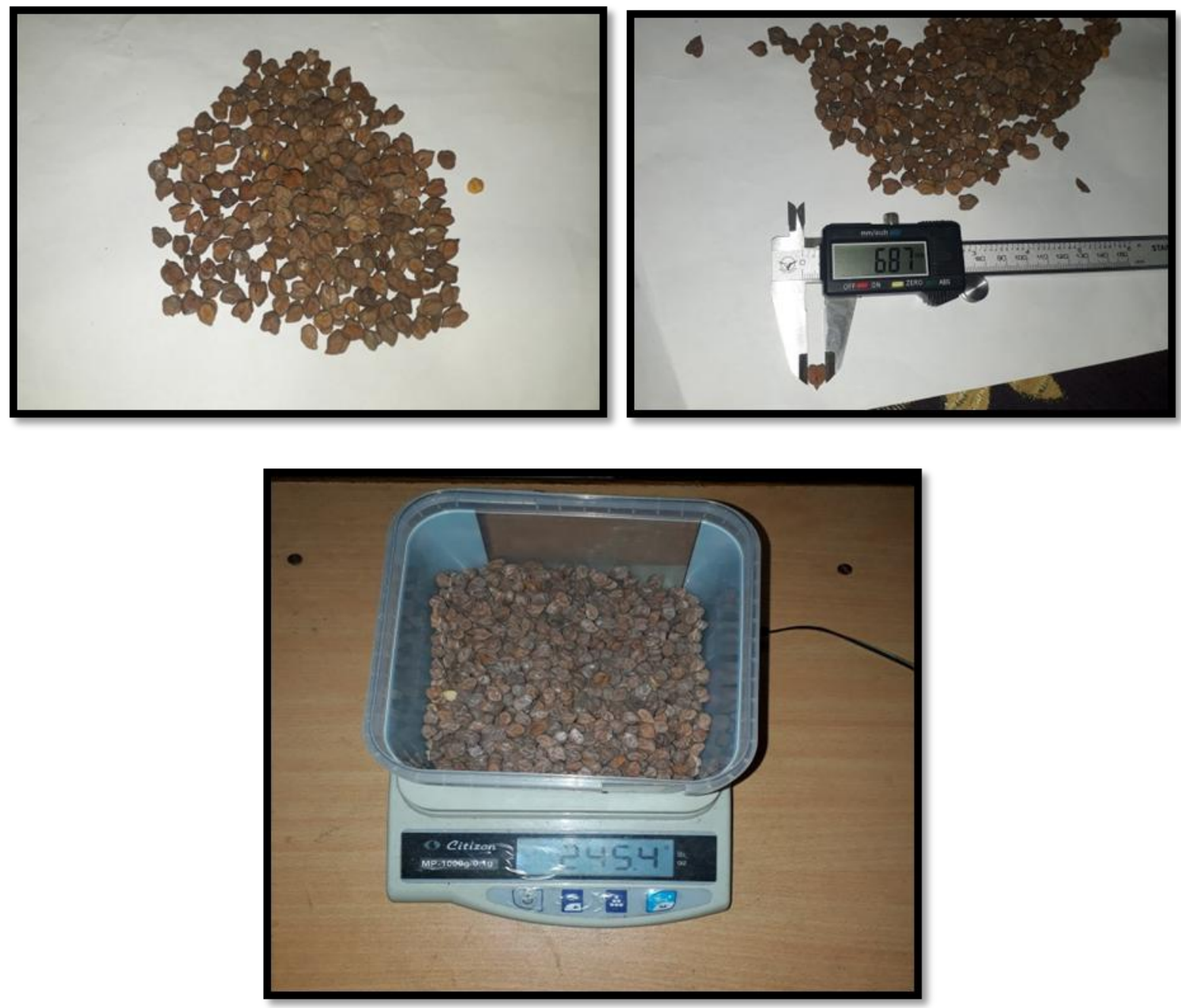

\section{References}

Agronomical recommendation 2018. Department of Agronomy, IGKV, Raipur.

Anonymous, 2016. Krishi Darshika, I.G.K.V., Raipur (C.G.). pp 5-6.

Anonymous, 2016.State concern Agriculture department, estimated area of 2015-16.

Ayman, H. AmerEissa, Mohamed, M.A., Moustafa, H., Abdul Rahman O. Alghannam, 2010. Moisture dependent physical and mechanical properties of chickpea seeds. Int J Agric \& Biol Eng, 3(4): 80-93.

Ghadge, P. N., Vairagar, P. R., and Prasad, K.,
2008. Some Physical Properties of Chickpea Split (Cicer arietinum L.), Agricultural Engineering International: the CIGR Ejournal. Manuscript FP 07 039. Vol. X.

Madamba, P. S., Driscoll, R. H. and Buckle, K. A., 1993.Bulk density, porosity and resistance to airflow of garlic slices. Drying Technology, 11(7):1837-1854.

Pandey MM. 2009. Country Report India Indian Agriculture an Introduction. Central Institute of Agricultural Engineering Bhopal, India. Presented in Fourth Session of the Technical Committee of APCAEM, Chiang Rai, Thailand 
Sahay, K. M. and K. K. Singh, 1994.Unit operations of agricultural processing. Vikas Publishing house Pvt. Ltd, New Delhi, 7-8.

Salah Ghamari, Khosro Mohammadi, Abdolvahed Khanahmadzadeh, Hadi, Goli 2014.Evaluation the Some
Physical Properties of Chickpea Seeds in Kurdistan Region of Iran International Journal of Agriculture and Forestry, 4(3A): 4-7.

Singhal, O.P. and Samuel, D.V.K., 2003. Engineering Properties of Biological Material. Saroj Prakashan.

\section{How to cite this article:}

Shubham Sinha, Ajay Verma and Shambu Singh. 2019. A Study on Some Physical and Engineering Properties of the Chickpea Seeds. Int.J.Curr.Microbiol.App.Sci. 8(11): 1504-1509. doi: https://doi.org/10.20546/ijcmas.2019.811.174 